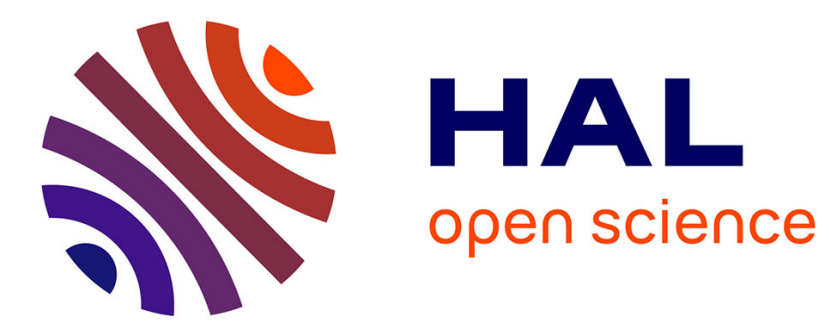

\title{
Commoning the seeds: alternative models of collective action and open innovation within French peasant seed groups for recreating local knowledge commons
} Armelle Mazé, Aida Calabuig Domenech, Isabelle Goldringer

\section{To cite this version:}

Armelle Mazé, Aida Calabuig Domenech, Isabelle Goldringer. Commoning the seeds: alternative models of collective action and open innovation within French peasant seed groups for recreating local knowledge commons. Agriculture and Human Values, 2020, 38 (2), 10.1007/s10460-020-10172-z . hal-02979790

\section{HAL Id: hal-02979790 \\ https://hal.inrae.fr/hal-02979790}

Submitted on 27 Oct 2020

HAL is a multi-disciplinary open access archive for the deposit and dissemination of scientific research documents, whether they are published or not. The documents may come from teaching and research institutions in France or abroad, or from public or private research centers.
L'archive ouverte pluridisciplinaire HAL, est destinée au dépôt et à la diffusion de documents scientifiques de niveau recherche, publiés ou non, émanant des établissements d'enseignement et de recherche français ou étrangers, des laboratoires publics ou privés.

\section{(c)(1)}

Distributed under a Creative Commons Attribution| 4.0 International License 


\title{
Commoning the seeds: alternative models of collective action and open innovation within French peasant seed groups for recreating local knowledge commons
}

\author{
Armelle Mazé 1,3 $^{10}$. Aida Calabuig Domenech ${ }^{1} \cdot$ Isabelle Goldringer ${ }^{2}$
}

Accepted: 9 October 2020

(c) Springer Nature B.V. 2020

\begin{abstract}
In this article, we expand the analytical and theoretical foundations of the study of knowledge commons in the context of more classical agrarian commons, such as seed commons. We show that it is possible to overcome a number of criticisms of earlier work by Ostrom (Governing the commons. The evolution of institutions for collective action, Cambridge University Press, Cambridge, 1990) on natural commons and its excludability/rivalry matrix in addressing the inclusive social practices of "commoning", defined as a way of living and acting for the preservation of the commons. Our empirical analysis emphasizes, using the most recent advances in the IAD/SES framework, the distributed and collaborative knowledge governance in a French peasant seed network as a key driver for reintroducing cultivated agrobiodiversity and on-farm seed conservation of ancient and landrace varieties. These inclusive peasant seed groups developed alternative peer-to-peer models of collaborative peasant-led community-based breeding and grassroots innovations in the search for more resilient population varieties. Our results highlight the various models of collective action within the network and discuss the organizational tradeoffs of opting out of peasant seed activities and recreating a shared collective knowledge base on the benefits of restoring cultivated agrobiodiversity. It helps us better understand how modern peasant seed groups function as epistemic communities which contributes to envisioning alternative agricultural systems.
\end{abstract}

Keywords IAD/SES $\cdot$ Peer-to-peer production · Participatory plant breeding $\cdot$ Knowledge economy $\cdot$ Innovation Institutional economics $\cdot$ Seed commons

\section{Introduction}

In the European context, peasant seed networks first emerged as a political movement in reaction to the private appropriation of crop genetic diversity by an increasingly concentrated global seed industry and as a means to foster the autonomy of peasants with regard to seed access (Bocci and Chable 2008; Demeulenaere 2014, 2018). ${ }^{1}$ Facing restrictive seed laws prohibiting the marketing (including

Armelle Mazé

armelle.maze@inrae.fr

1 Université Paris-Saclay, INRAE, AgroParisTech, UMR SADAPT, 75005 Paris, France

2 Université Paris-Saclay, INRAE, CNRS, AgroParisTech, GQE - Le Moulon, 91190 Gif-Sur-Yvette, France

3 INRAE UMR SADAPT, 16 rue Claude Bernard, 75231 Paris Cedex 05, France the free exchange) of noncertified peasant seeds and a blatant lack of research on hardier and more resilient seed varieties for low input or organic farming systems, these networks also developed innovative strategies, including experimentation and research activities allowed under the seed legislation, ${ }^{2}$ in their search for landraces and ancient varieties better suited to their needs. They thus initiated new forms of distributed and collaborative plant breeding that more effectively blended the experiential and situated

\footnotetext{
${ }^{1}$ In this article, we use the terms "peasant" and "peasant seeds" because they reflect the ontologies used by the actors themselves as distinctive political markers (Osman and Chable 2009; Demeulenaere 2014, 2018).

${ }^{2}$ EU directive 66/402/EEC, dated the 14th of June, 1966, allows derogations to the marketing of certified seed in relation to (i) bred seed of generations prior to the basic seed; (ii) for tests or for scientific purposes; (iii) for selection work; and (iv) for seed as grown and marketed for processing, provided that the identity of the seed is ensured (Art.3). However, national legislation in many European countries remains restrictive.
} 
knowledge of peasants with scientific advances in population genetics (Goldringer et al. 2012; Rivière et al. 2013; Demeulenaere et al. 2017).

In this article, we analyze, based on recent theoretical advances on knowledge commons (Hess and Ostrom 2003, 2007; Hess 2012; Frischmann et al. 2014), the role of the distributed and collaborative knowledge governance adopted by a French peasant seed network, the "Réseau Semences Paysannes" (RSP) and its "Participatory Wheat Breeding Group" (hereafter PWBG), on small grain cereals. A growing body of literature emphasizes the effects of seed exchanges in and their positive or negative impact on the maintenance of genetic diversity in plant populations and the restoration of cultivated agrobiodiversity (Thomas et al. 2011; Pautasso et al. 2013; Calvet-Mir et al. 2012). However, in the face of massive collective knowledge and memory loss about landraces and ancient varieties, recreating shared collective knowledge about cultivated agrobiodiversity and its benefits for more sustainable and resilient agriculture was a priority for a number of peasant seed groups (Brac de la Perrière 2014; Lewrouw et al. 2014). In a recent study, Gilbert (2013) also observed the "deskilling" of UK horticultural producers using seed catalogs as the sole source of knowledge and germplasm, simply purchasing seeds rather than saving or swapping them. A better understanding of how local peasant seed communities in Europe support their innovative grassroots activities, the processes of collective knowledge restoration and the models of collective action is still needed.

Our original contribution here is to provide deeper insights into the analytical and theoretical foundations of the study of knowledge commons in the context of more classical natural and agrarian commons, such as seed commons. Our analysis is sustained by the most recent advances in the IAD/SES ${ }^{3}$ framework (Ostrom 2009; Hess and Ostrom 2003, 2007; Frischmann et al. 2014). We show that it is possible to overcome, as was stressed by Hess (2010), a number of criticisms of earlier work by Ostrom (1990) and the usual interpretation of the excludability/rivalry matrix and its social dilemma in addressing the social practices of "commoning", defined as a way of living and acting for the preservation of the commons (Linebaugh 2008; Bollier and Helfrich 2012; Euler 2018). We also demonstrate that peasant seed initiatives provide particularly relevant empirical cases to develop a better understanding of knowledge commons, in both their material and immaterial dimensions, and to address the specific cognitive, social and organizational framings at stake in individual and collective learning in the context of knowledge restoration (Douglas 1986; Hess and

\footnotetext{
3 IAD/SES framework: Institutional Analysis and Development/ Social-Ecological System Framework.
}

Ostrom 2003; North 2005; Hess 2012). Interestingly, our study highlights the capacity of local peasant seed initiatives to develop innovative research collaborations and to more effectively blend the peasant's experiential and situated knowledge with the most recent scientific advances in population genetics (Enjalbert et al. 2011; Goldringer et al. 2012; Demeulenaere et al. 2017).

The research questions addressed in our study are thus: How are artifactual and material aspects and their social and cognitive counterparts interrelated in knowledge commons? How do they influence individual and collective learning processes as well as knowledge accumulation and dissemination? What are the roles of socialization and of material artifacts in knowledge co-creation, transmission and dissemination among participants? How do the various participants and their pooling arrangements structure their interactions and the knowledge they produce and share? The article is organized as follows. First we provide a short overview of the analytical background on knowledge commons. Second, we introduce the methodology and data treatment. Third in the "Results and analysis" section, we presents the specific institutional context in France, the diversity of models of collective action and self-governance, observed across peasant seed groups, before comparing two contrasted seed governance models: Pétanielle and Graine de Noé for organizing seed activities. Last we conclude and discuss a number of remaining challenges.

\section{Analytical framework}

In this section, we discuss a number of analytical extensions in the study of knowledge commons (Hess and Ostrom 2003, 2007; Madison et al. 2010; Frischmann et al. 2014) of earlier work by Ostrom (1990) on natural and agrarian commons and their interrelations when applied to seeds.

\section{Commoning the seeds: restoring local knowledge commons}

In the recent literature, a growing number of studies have considered the role of alternative seed systems as "commons", e.g., shared collective resources by local place-based peasant communities, but also as involving new innovative forms of civic engagement and stewardship towards a larger public (Wirz et al. 2017; Girard and Frison 2018; Wolter and Sievers-Glotzbach 2019; Mazé et al. 2021). Inspired by the Open Source movement, most debates have focused on the legal options for preventing the patenting of genetic resources and their privatization (Kloppenburg 2010, Wirz et al. 2017; Kotschi and Horneburg 2018). In Europe, peasant seed groups have played a leading role 


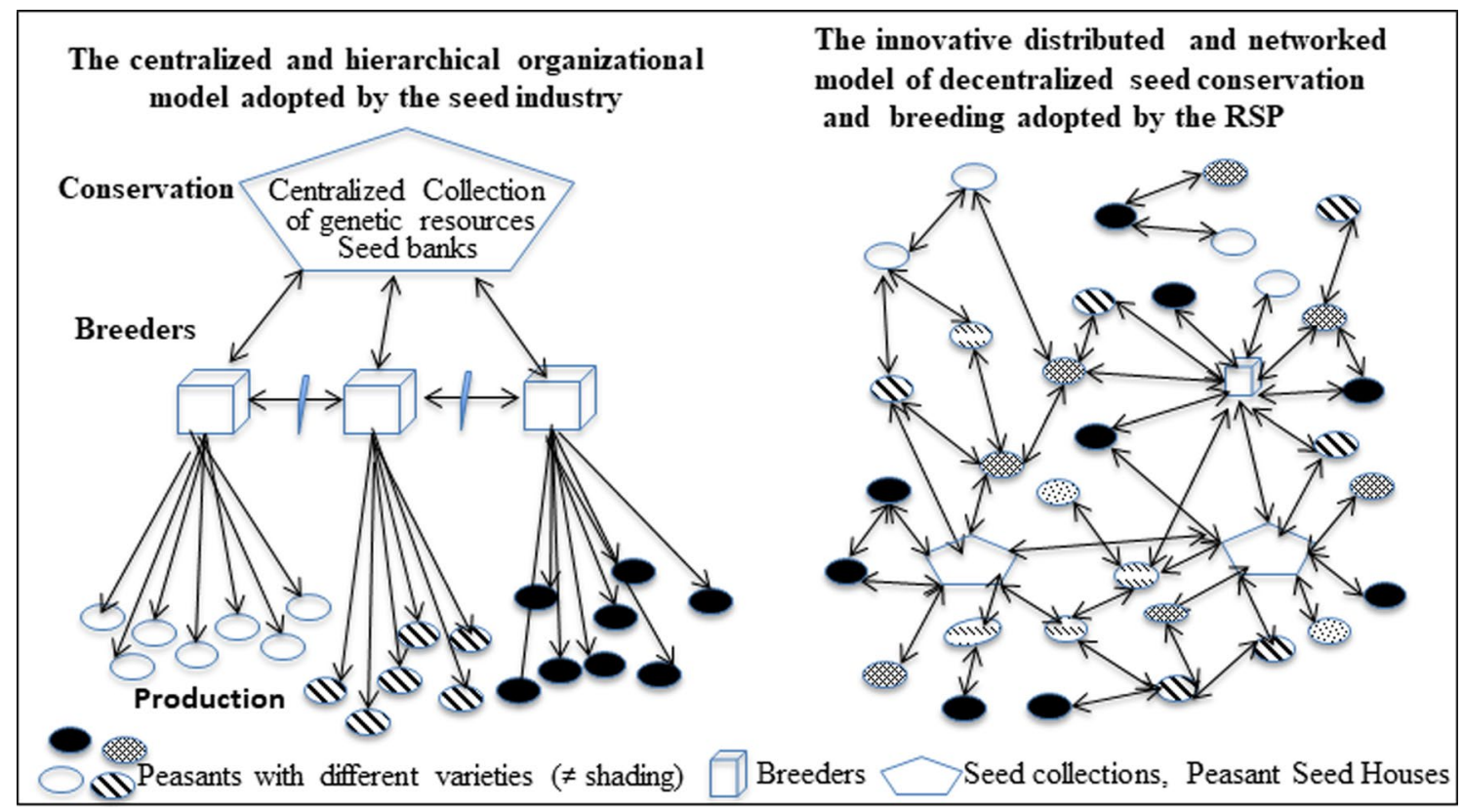

Fig. 1 The hierarchical organizational model adopted by the seed industry (left) and the distributed model adopted by the PWBG (right) (adapted from Bonneuil and Thomas 2009)

in the reappropriation of peasant seed rights through the so-called "liberate our seeds" movement. They defend the rights of peasants to breed and exchange seeds, which can be saved and are not patented, genetically modified, owned or controlled by seed companies (Demeulenaere 2014, 2018; Girard and Frison 2018).

A less investigated issue in the literature was pointed out by Bonneuil and Demeulenaere (2007). They considered peasant seed groups and their innovative models of collective action as a possible move towards new organizational models of distributed "peer-to-peer genetics" and grassroots innovations, in opposition to the top-down and vertical organization of the mainstream seed industry (Bonneuil and Thomas 2009). Figure 1 illustrates the differences between the pyramidal and top down vertical labor division between farmers and breeders adopted by the seed industry (left side) and the distributed organizational models adopted by the RSP and its local peasant seed groups (right side). The potential benefits of adopting distributed and networked polycentric forms of grassroots innovation, such as in the case of the RSP, rather than the delegated and hierarchical governance are increasingly emphasized by sustainability studies (Andersson and Ostrom 2008; Ostrom and Cox 2010).

While reasserting seed freedom and open access to seeds as fundamental peasant rights, the approach adopted by the RSP differs from that of other seed activist groups, such as Kokopelli in France, in its favoring of socially constrained exchange within local seed groups comprising peasants, gardeners and amateurs (Demeulenaere 2014). As stressed by Ostrom (1990), there is a difference between commons managed in common and commons managed as a "free-for-all", which Hardin (1968) describes as the so-called 'tragedy of the (open access) commons'. ${ }^{4}$ It is only because the commons are collectively organized that they can be a viable alternative to market or state management through certain forms of collective action and social self-organization to be analyzed (Ostrom 1990, 2005, 2009, 2011).

Over the last few years, the study of the commons was mainly guided by Musgrave/Ostrom's classification and its criteria of (i) ease of exclusion (excludability) and (ii) intensity of "joint consumption" or "joint use" (rivalry), suggesting the need to regulate potential overuse and competition for limited and exhaustible natural resources by maintaining small size groups and limiting members (Olson 1965; Ostrom and Ostrom 1977; Ostrom 1990, 2003). Other recent studies called for moving beyond this classification and its strong focus on exclusion as a key attribute of the collective action problem, as exclusion does not reflect the positive social values of "commoning" and the related norms of cooperation, reciprocity and solidarity (Linebaugh 2008;

\footnotetext{
${ }^{4}$ A useful distinction introduced by Ostrom $(1990,2005)$ is that between the reproductive "resource system" managed in common (here, the seed commons) and the "resource unit" (the seeds) that can be privately appropriated or used, as defined by seed laws and other informal rules.
} 
Bollier and Helfrich 2012; Euler 2018). The challenges faced by peasant seed initiatives, then, give us the opportunity to explore less investigated, but clearly identified, theoretical aspects of commons research (Ostrom and Ostrom 1977; Ostrom 2002, 2003; Hess and Ostrom 2007).

The main challenge faced by the RSP's peasant seed groups is not to limit members and impose restrictions on resource access (here, seeds) but rather to enroll, as part of their political strategy, as many peasants and supporters of their cause as possible who may be interested in the preservation of landraces and ancient varieties, as well as the restoration of cultivated agrobiodiversity (Brac de la Perrière 2014; Demeulenaere 2014). Moreover, beyond seed exchanges, what truly matters for the RSP is the restoration of shared collective knowledge and field expertise among peasants about landraces and ancient varieties (Brac de la Perrière 2014). Their concern is thus to overcome the underprovision of public or collective goods that could benefit all in a situation of "coproduction" or "joint production" of shared collective and individual knowledge requiring the participation and collaboration of many (Ostrom and Ostrom 1977: Ostrom 2003). It differs from situation of "joint consumption" usually analyzed in the literature. Here, the more members there are in an inclusive group, the more individuals there are who can bring and share their additional resources to develop alternative seed systems that can be enjoyed by all. Such "inclusive groups" (Olson 1965) ${ }^{5}$ have received less attention in the literature (Ostrom 2003).

\section{Knowledge ecosystems, collective action and self-governance}

In the literature, the study of traditional natural and agrarian commons has been partially disconnected from studies on knowledge and cultural commons (Hess and Ostrom 2007; Hess 2012; Madison et al. 2010; Frischmann et al. 2014). Until recently, knowledge commons were mainly associated with scholarly knowledge and formal systems of property rights, such as IP laws, in the context of the spread of digital technologies and the possible threat of a second enclosure of the "intangible commons of the mind" (Boyle 2003; Hess and Ostrom 2007, Frischmann et al. 2014). More recently, Hess (2012) proposed extending analysis to all forms of "useful knowledge, whatever their forms in which they are

\footnotetext{
5 Olson (1965) also predicted that bargaining and strategic interactions associated with the classic social dilemma of possible noncooperative behavior or individual "free riding" would be less intense and managed differently in inclusive groups (Ostrom et al. 1994; Ostrom 2003), as observed in our study. Other dimensions promoting cooperative behaviors, such as self-determination and intrinsic motivation, are here at stake.
}

expressed or obtained" (p. 14), including indigenous, vernacular, scientific, as well as cultural and creative works.

Unlike the first generation of IAD research (Ostrom 1990), Hess and Ostrom (2007, p. 14) also found it essential to adopt a broader approach to the "commons" by considering the knowledge ecosystems, the models of collective action and self-governance, in which they are nested and the way they interact with the complex systems of natural and socially constructed environments (Levine 2007; Hess 2010). Knowledge and the set of cognitive representations (or mental models) and underlying values supporting the social processes of individual and collective learning are also key aspects of the sustainability of SES (Hess and Ostrom 2003; Ostrom 2009; Pahl-Wostl 2009). ${ }^{6}$ The importance of actors' values and representations with respect to the human/nature relationship, fiscal equivalence, redistributional equity, accountability and sustainability are also crucial in the dynamics of collective action (Ostrom 2011). Based on these considerations, it is possible to answer some of the critics calling for the reintroduction of the social practice of "commoning" as a way of living and acting for the preservation of the commons, in contrast to the treatment of commons only as resources, and to leverage the crucial role of the voluntary and inclusively self-organized activities of peers satisfying their specific needs (Linebaugh 2008; Bollier and Helfrich 2012; Euler 2018). ${ }^{7}$

Madison et al. (2010) compared the research on knowledge commons with that on more traditional natural and agrarian commons and identified several differences. Participants not only have to share existing resources but must also engage in a set of generative practices, in maintaining, sharing and producing knowledge resources, that are intangible and involve situated knowledge that is both immaterial and material, e.g., ideas, discrete artifacts and facilities (Hess and Ostrom 2003; North 2005). Linebaugh (2008) suggested that the commons is not only a resource but also "an activity, and if anything, it expresses relationships in society that are inseparable from relations to nature" (p. 279).

In the literature, knowledge is usually considered a public good, as defined by the Musgrave/Ostrom classification, free and open access to which must be guaranteed as a fundamental human right (Kaul 2003; Hess and Ostrom 2007). When considered as a generative practice, coproducing,

\footnotetext{
${ }^{6}$ The IAD/SES framework has been continuously amended to better integrate these social and cognitive dimensions, and by shifting from "resources users" to "actors" (McGinnis and Ostrom 2014).

7 The term "commoners", while mainly used in the English historical context, refers to people living of and being involved with the commons (Linebaugh 2008; Singh 2017). There is often no equivalent term in other languages. The French peasants surveyed in our study do not refer to themselves as "commoners".
} 
creating and preserving shared common knowledge requires the active participation and engagement of individuals, raising specific problems of collective action, called here "knowledge dilemma", different from other social dilemmas. Knowledge commons are thus defined by Frischmann et al. (2014) as "the institutionalized community governance of the sharing and the creation, of information, science, knowledge, data, and other types of intellectual and cultural resources" that we inherit, use, experience, interact with, change and pass on to future generations through the cultural environment. Typical threats to knowledge commons are commodification, enclosure, degradation, and non-sustainability (Hess and Ostrom 2007). In contrast to close traditional communities with tight social bonds, the relevant community herein is not necessarily determined by geographical proximity, homogeneity or small numbers but by its numerous connections for knowledge sharing, cocreation and collective learning (Madison et al. 2010).

\section{Democratizing innovation: the distributed peer-to-peer self-governance of user innovation}

In the literature, agricultural knowledge is often viewed as traditional (Reyes-Garcia et al. 2018), though a well-established body of studies also considers peasants as key innovators and acknowledges their role in the development of more sustainable agricultural systems (Darré 1996; Dolinska and D'Aquino 2016). In their study, Bonneuil and Demeulenaere (2007) also identified peasant seed groups as "communities of practice", as well as "epistemic communities", with shared practices and tangible products, an identity and history but also a body of shared knowledge surpassing that of any one individual. This body of knowledge incorporates the experiential and situated knowledge that peasants derive from their day-to-day field observations and situated natural experiments in their specific environment (Ostrom 2009). In the IAD/SES literature, the use of local ecological knowledge (LEK) is a key dimension for making governance regimes more adaptive and sustainable by facilitating collective learning through more collaborative arrangements among actors (Berkes et al. 2000; Acheson 2003; Ostrom 2005). However, with its rediscovery, traditional LEK does not have to be mired in the past but remains an ever-evolving and creative knowledge-practice-belief complex (Berkes et al. 2000; Berkes 2009).

In the face of restrictive seed laws, the rise of peasant seed groups in the European context represents an interesting attempt to define new organizational models of open innovation, defined by Von Hippel (2005) as efforts to democratize innovation in which the final users (here, peasants) are no longer seen as "users", but also as "actors" involved in joint collective learning and peer-to-peer knowledge co-creation
(Harkoff and Lakahni 2016). ${ }^{8}$ Whereas scientific knowledge is usually viewed as needed to enhance efforts to sustain SESs (Ostrom 2009), peasant seed initiatives, such as the RSP, were first build upon values of emancipation and self-empowerment of peasants, but also upon a critic of science and of the dominant paradigms in breeding research (Demeulenaere et al. 2017). In contrast to traditional commons involving local homogeneous communities with tight social bonds (Ostrom 1990), peasant seed groups in Europe provide an interesting avenue for further investigation of situations in which self-governance occurs under less favorable conditions, especially in a context where peasant seed groups are still subject to numerous misconceptions that limit their formal recognition and real integration into public policies (Coomes et al. 2015).

In the IAD/SES literature, recent studies have stressed the potential benefits of adopting a network perspective, which presents the advantages of being more flexible and facilitates the adoption of participatory governance, which usually involves emancipation and legitimization and is potentially effective for solving existing local environmental issues (Andersson and Ostrom 2008). Under certain conditions, such distributed and networked forms of polycentric governance could even outperform the traditional top-down and hierarchical governance such as that employed by the mainstream seed industry, as represented in Fig. 1. By giving more autonomy to local actors to develop their own rules, individual and collective learning are enhanced through institutional diversity, but possibly at the expense of higher coordination costs (Andersson and Ostrom 2008; Ostrom 2014). The question, then, is how these alternative models of polycentric and open networked forms of collective action help or hinder innovativeness, learning, adaptability, trustworthiness, cooperation, and the achievement of more effective, equitable, and sustainable agroecosystems.

\section{Methodology and data}

Our analysis concentrates on the PWBG of the RSP and its 14 collective groups as well as several individual peasants involved in 2018. ${ }^{9}$ Table 5 in the Annex presents the

\footnotetext{
${ }^{8}$ Pénin (2011) differentiated Open Source Innovation (OSI), discussed by Kloppenburg (2010) in the context of plant breeding, from the concept of "Open Innovation" as defined by Von Hippel (2005), in which end users' and grassroots community-based innovations are central, as promoted by the maker movement and its motto "do-ityourself" (DIY). This latter concept is referenced in our study.

9 A year before our survey, in 2017, the PWBG officially included, according to the RSP website, 12 collective groups, 87 individual peasants actively involved in the PWBG, 15 facilitators and 10 other members from research and technical institutes, such as INRA, ITAB, CIRAD and the Agricultural College of Purpan.
} 


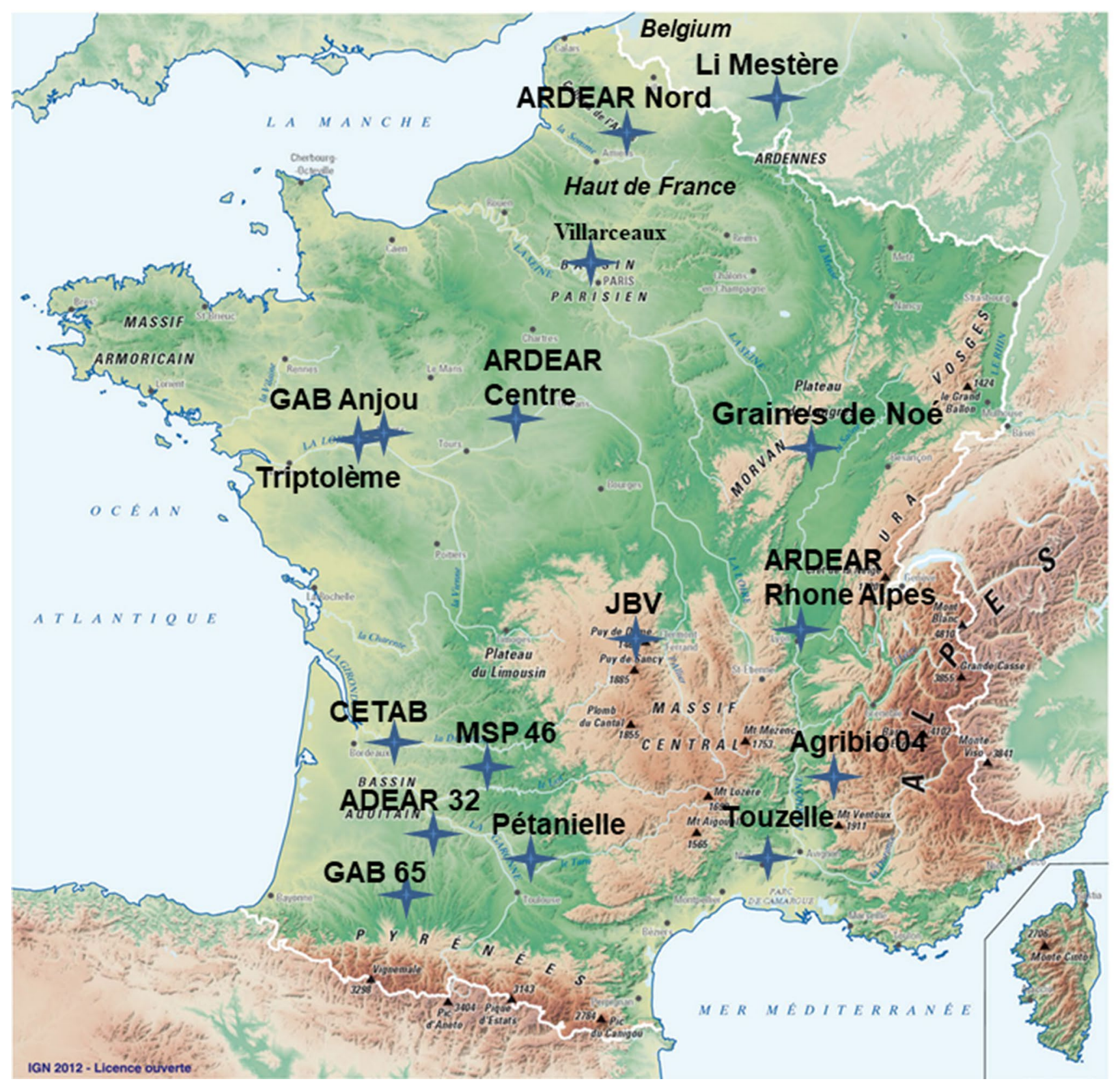

Fig. 2 Locations of the local peasant seed groups involved in the PWBG

main characteristics of the local seed groups involved in the PWBG. They are all located in noncontiguous territories representing different SESs and therefore cover a wide variety of soil conditions and climates, including oceanic, semi-oceanic, mountainous and Mediterranean climates in France and, more recently, in Belgium (Fig. 2). This specific spatial organization allows for better integration, facilitation and reinforcement of the adaptability of seed populations and crop genetic diversity in relation to local landscapes, soil and climate conditions, as well as local agricultural practices.
Our methodology builds upon the most recent theoretical and analytical developments within the IAD/SES framework, allowing a broader approach to the social and knowledge aspects of collective action and to the adaptive governance of SES (Ostrom 2009; Hess 2012; McGinnis and Ostrom 2014; Cole et al. 2019). The IAD/SES framework was used here as a diagnostic guideline to analyze the formal and informal rules-in-use within the PWBG groups and the political and institutional context framing their action arenas (Ostrom and Cox 2010; Ostrom and Basurto 2011). Figure 3 summarizes the main components of an IAD/SES diagnostic 


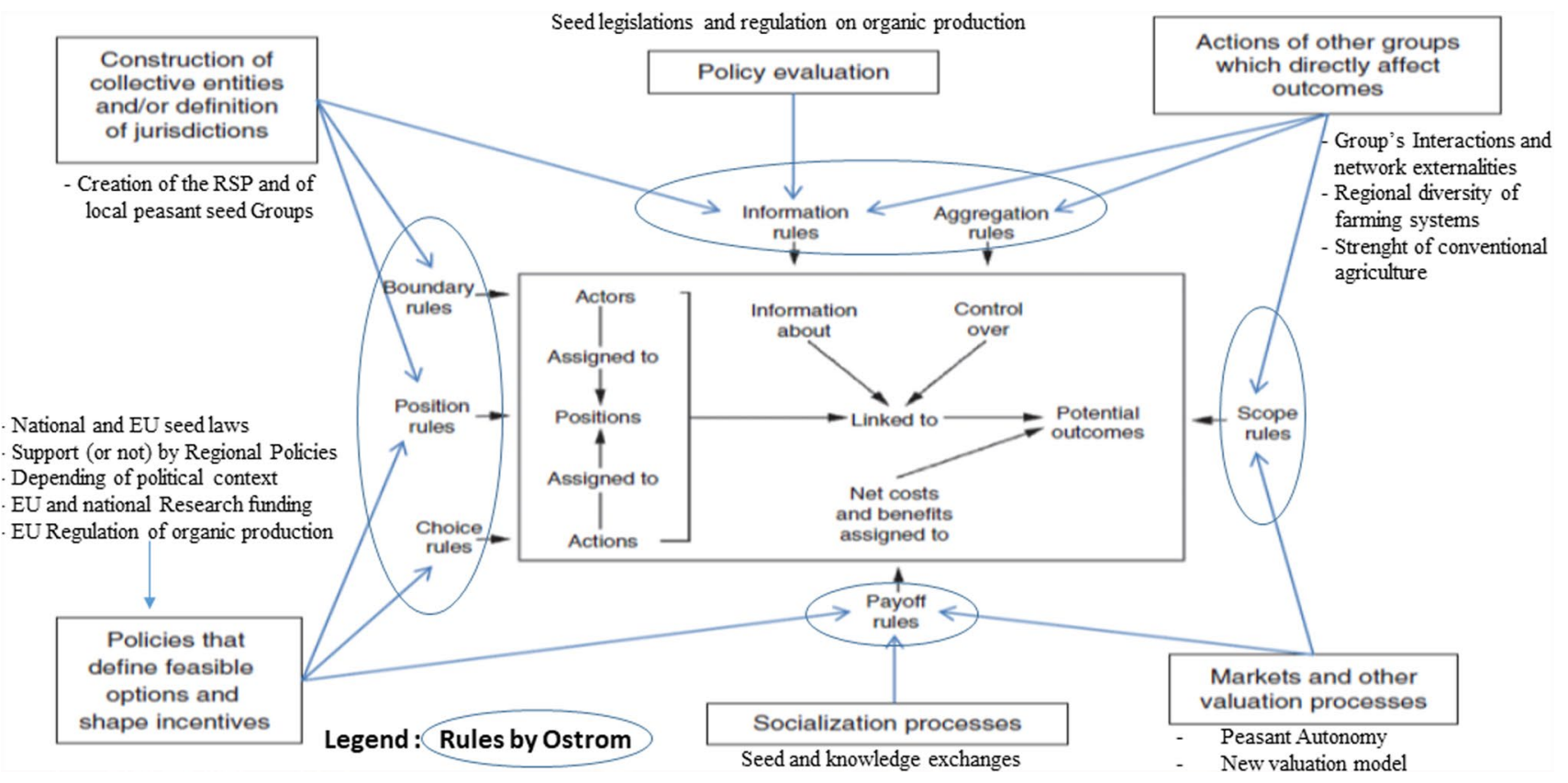

Fig. 3 Characterization of the action arenas of peasant seed groups (adapted from Cole et al. 2019)

characterizing the action arenas in which the local PWBG groups are embedded.

Empirical data were collected through twenty in-depth qualitative semi-structured interviews conducted with all the facilitators or key peasants within the fourteen local groups, two individual peasants (see Table 5 in Annex), a former PWBG facilitator and founding member of the RSP and with researchers involved in the PWBG since its inception. The semi-structured interviews were conducted using six open-ended questions covering the different variables identified in Fig. 3: (i) the local context of the collective groups (location, size, history, objectives, motivations, types of actors, varieties, activities, human and financial resources, farming practices, value creation, etc.); (ii) formal and informal internal rules; (iii) knowledge creation and dissemination; (iv) relations with individual members and groups, the degree of involvement, motivation, and local partnerships; (v) challenges, lock-ins and risk perception, and (vi) perspectives and challenges. In addition, legal and internal documents (statutes, procedural rules, and membership forms) were collected and analyzed. Specific attention was paid to the political and institutional factors, the socialization processes and valuation models, as well as the missions and resources (human, financial, and material) influencing the specific "rule configurations" and models of collective action (Ostrom 2011). Figure 3 provides an overview of the rules analyzed in the IAD/SES framework (Ostrom 2009; McGinnis and Ostrom 2014). Our analysis also emphasized the way each local seed group organizes its seed activities, e.g., seed prospection, conservation, breeding, propagation, experimentation, and the implications in terms of knowledge co-creation and dissemination for recreating local knowledge commons on landraces and ancient seed varieties.

\section{Results and analysis}

Before analyzing more precisely the various models of collective action and self-governance adopted by the peasant seed groups involved in the PWBG, and comparing two contrasted seed governance models: Pétanielle and Graines de Noé, we describe first some key elements of the institutional and legal contexts that may explain the progressive structuration of peasant seed networks and the specific pathways observed in France compared to other countries.

\section{Against the rules: the political emergence of peasant seed networks in France}

The RSP, after its creation in 2003, rapidly assumed a structuring role at the national level as outlined by its mission to (i) develop and encourage networking activities that enhance crop biodiversity on farms and in gardens; (ii) create awareness about legal issues surrounding the production and commercialization of seeds; and (iii) achieve recognition from both regulators and public institutions of peasant seeds and their role in the preservation and management of cultivated biodiversity. In France, the threat posed by GMO contamination in supposedly "GMO-free" certified seed lots and the tentative establishment in 2002 of a legal obligation for 
organic producers to show evidence that their seeds were organically produced, even though only certified seed companies could provide such evidence, strengthened the opposition and helped raise awareness about the urgent need for peasants to better control seed origins (Demeulenaere 2014).

With the growing standardization of modern varieties, mainly selected based on their yield performance (Wattnem 2016), a number of peasants began to search out local landraces and ancient varieties better suited for diverse uses and specific needs, such as animal feeding, straw production, or transformation into specialty bread. The stark lack of research on the development of more resilient and hardy seed varieties for low input or organic farming systems was another key issue (Bocci and Chable 2008). The reintroduction of ancient varieties rapidly emerged as a solution to the dominance of large seed companies and the restrictions imposed on free access to landrace seeds in public collections (Osman and Chable 2009; Brac de la Perrière 2014). ${ }^{10}$ Whereas landraces and ancient varieties often produce lower yields than modern varieties, added economic value is created through better social-ecological fit (alignment) with their specific terroir, improved pest control and resilience, and increased farm autonomy through the reduction of external inputs or new value creation strategies (specialty breads, local distribution channels, agro-tourism, etc.) (Enjalbert et al. 2011; Thomas et al. 2011). Over time, the activities of the RSP, which included more than 90 local seed groups in 2018, were progressively structured into subgroups defined by plant species: small grain cereals, arboriculture, corn and forage crops, vegetables and grapes. Each subgroup developed specific know-how on plant breeding in its specific reproduction domain (self-pollinating, cycles and temporality, allogamous/heterogamous, etc.). The seeds are considered by the RSP members not only as genetic resources but also as dynamic living matter evolving in close interaction with their local terroir and their specific agroecosystems and related farming systems (Demeulenaere 2013, 2014).

\section{Restoring cultivated agrobiodiversity: recreating a shared common knowledge base}

In the literature, in situ (or on-farm) agrobiodiversity conservation is usually viewed as a way to ensure the maintenance of cultural information (knowledge and traditions), especially in countries from the Global South (Calvet-Mir

\footnotetext{
$\overline{10}$ A key step was that the PWBG members reclaimed access rights to the landraces and ancient varieties retained by the National Seed Collection for small grain cereals managed by the public research institute INRA in Clermont-Ferrand, which is in charge of the ex situ conservation of small grain cereals in France (Demeulenaere 2014).
}

et al. 2012). In contrast, cultivated agrobiodiversity has been reduced considerably in many European countries, especially in France, as a result of the modernization of agriculture (Bonnin et al. 2014). Agricultural modernization has also deeply transformed local peasant communities, so there is often no remaining individual knowledge of specific seed attributes and their adaptive responses to various farming practices and soil-climate environments (Brac de la Perrière 2014; Lewrouw et al. 2014). In such a context, knowledge restoration could thus not be based on maintained traditional knowledge but would also require a specific effort to recreate a shared common and collective knowledge about landraces and ancient varieties.

A fundamental approach of the RSP with regards to this process of knowledge restoration is the stimulation of both individual and collective learning and the day-to-day practice of seed handling and experimentation. This approach follows a logic of "learning by doing" to facilitate the acquisition by individual peasants of experiential and situated knowledge about the specific attributes of population varieties and their adaptation to local terroirs combining specific agroecosystems and farming practices. The aim was for the RSP to foster closely interconnected individual and collective learning processes based on what Polanyi (1969) identified as a recombination of personal knowledge through individual and collective field experimentations, socialization and sharing in a dialogical mode. Knowledge sharing is also at the core of the social practices of commoning defined as a way of living and acting for the preservation of the commons (Bollier and Helfrich 2012).

Traditionally, peasants have always practiced phenotypic selection, also called "mass selection" (in French, "sélection massale"), differentiating their plant populations by the phenotypic traits that seem to be the most interesting depending on the local climate and soil conditions, land plots and soil, the earliness of varieties, and farming practices and ultimate use (on-farm animal feeding, straw production, bread-making, processing, etc.). A further step was taken in 2006, when several RSP peasants were invited, after a joint meeting with Salvatore Cecarrelli in Poitiers (France), on a field trip to Syria highlighting the potential benefits of peasant-led collaborative breeding (Ceccarelli and Grando 2007). It served as a trigger for the start of the PWBG and the interest of RSP peasants in developing new know-how and skills related to cereal plant breeding, as well as new seed activities, such as seed exchanges and the development of cross-breeds from peasant landrace varieties. The result was the formal establishment of the PWBG, which benefitted from specific resources allocated by the RSP through the help of a dedicated RSP facilitator and collaborations with a research team (Goldringer et al. 2012; Demeulenaere and Goldringer 2017). 
Table 1 Knowledge domains addressed by peasant seed groups

Domain of knowledge Details (Know what, know how)

Knowledge of landraces and ancient varieties

Knowledge of cultivation techniques for ancient and landrace varieties

Knowledge of seeds

Breeding knowledge

Knowledge of cereal processing (milling, bread-making, etc.)

Knowledge of the collective management of the peasant seed house
Where do landraces and ancient varieties come from? What is the genealogy of seed lots and what are the names of the peasants who produced them? What are the specific phenotypic attributes of varieties (grain yield, height, straw, color, etc.)?

What are the specific cultivation techniques for landraces and ancient varieties compared to modern varieties? How do they respond to specific soil and climate environments and yearly variations, sowing and harvesting techniques and timing, crop rotation, and weed species, and what is their lodging and disease resistance, etc.?

How can seeds be conserved? How are seeds selected, cleaned, stored, packed and tagged?

Farm visits are made to see their seeding implements and sorters, how they work, the building and the material and organizational layouts

What are the general principles of genetic selection and population genetics, and what are the genetic mechanisms? What are the practical aspects of choosing, plucking the ears, etc.?

What are the flour milling techniques? What varieties are best suited for bread-making? Bakehouse visits are made to see their technical arrangements (type of bread oven, natural yeast, temperature management, etc.)

How do the peasants organize themselves? How is the peasant seed house managed? How do they know who keeps the different seed varieties? How do they manage the different varieties and collections?
Rather than adopting other forms of "participatory varietal selection" (Sperling et al. 2001), the PWBG opted to pursue peasant-led collaborative breeding in which scientists, specifically, population geneticists, merely provided technical support to the peasants' own systems of breeding, population varietal selection and seed maintenance (Goldringer et al. 2012; Rivière et al. 2013; Demeulenaere et al. 2017). ${ }^{11}$ Through the RSP activities, individual knowledge acquisition and re-creation were harnessed via collective knowledge exchanges and familiarization with the practical experiences of other peasants in handling landraces and ancient varieties, as well as restoring cultivated agrobiodiversity. Through these seed activities, the importance of the social practices of commoning as a way of living and acting for the preservation of the commons becomes clear (Bollier and Helfrich 2012). Table 1 summarizes the various knowledge domains covered by the exchanges in the peasant seed groups.

\footnotetext{
11 Demeulenaere et al. (2017) introduce the term "collaborative breeding", instead of "participatory breeding", to better reflect the equal position of the peasants and researchers.
}

\section{Towards distributed and collaborative breeding as a reflexive governance model}

In opposition to the mainstream static and fixed vision of seed conservation, a key principle structuring recent peasant seed initiatives is that landraces and ancient varieties are the result of a co-evolution among humans, plants and territories. Whereas early core PWBG members were attracted by the idea of dynamic seed management and on-farm conservation of landraces and ancient varieties as a strategy to reintroduce crop genetic diversity in the fields, others also rapidly engaged in innovative breeding strategies and considered "new" or "interesting" seed types, such as crossbreeds, heterogeneous crop populations, "seed mixtures", or even foreign varieties (Rivière 2014). By doing so, they also reasserted their status as "peasant-researchers", equalizing their researcher position in the processes of breeding and the co-creation of knowledge about seed management and dynamic on-farm conservation of crop genetic diversity (Demeulenaere 2014; Demeulenaere et al. 2017).

By acknowledging the central role of peasants as knowledge holders and key actors in the dynamics of on-farm conservation of agrobiodiversity, the PWBG proposed a shift from 
Table 2 Three main models of collective governance in the PWBG collective groups

\begin{tabular}{|c|c|c|c|}
\hline Main orientation of the group & Specialized conservation-propagatio & -oriented model of governance & Value-oriented model of governance \\
\hline Model & Model 1 without facilitator & Model 2 with a facilitator & Model 3 outsourcing \\
\hline Characteristic & $\begin{array}{l}\text { A distributed governance model } \\
\text { without a facilitator }\end{array}$ & $\begin{array}{l}\text { A governance model with a facilita- } \\
\text { tor }\end{array}$ & $\begin{array}{l}\text { Governance by another organization } \\
\text { (co-op, national park, etc.) }\end{array}$ \\
\hline $\begin{array}{l}\text { Organizational characteristic } \\
\text { for each type }\end{array}$ & $\begin{array}{l}\text { Less formalized, stronger informal } \\
\text { coordination among peasants; no } \\
\text { compensation scheme }\end{array}$ & $\begin{array}{l}\text { More formalized rules, with a } \\
\text { facilitator and a compensation } \\
\text { scheme }\end{array}$ & $\begin{array}{l}\text { Formalized rules and contracts with } \\
\text { a price system for derived final } \\
\text { products (flour, bread, etc.) }\end{array}$ \\
\hline Core groups or individuals & $\begin{array}{l}\text { Syndicat de Touzelle, ARDEAR } \\
\text { Rhone Alpes } \\
\text { Triptolème, Pétanielle, Limestère. }\end{array}$ & $\begin{array}{l}\text { Graines de Noé, } \\
\text { CETAB }\end{array}$ & $\begin{array}{l}\text { AgriBio 04, } \\
\text { GAB } 65\end{array}$ \\
\hline More recent group member & $\begin{array}{l}\text { GAB Anjou, MSP } 46 \text {, } \\
\text { ADEAR } 32\end{array}$ & ARDEAR Nord & \\
\hline
\end{tabular}

Legend: The groups exclusively specializing in peasant seeds are in bold

traditional approaches to research on plants and seeds towards more collaborative, dynamic and egalitarian approaches (Enjalbert et al. 2011; Goldringer et al. 2012; Demeulenaere 2014). First, the PWBG was clearly oriented towards peasants' problems, their shared values and their objectives in terms of seed autonomy and seed adaptation to their terroir. ${ }^{12}$ By explicitly addressing the selection preferences and the experiential and situated knowledge of peasants, in functional, experiential, aesthetic or emotional dimensions, priority was clearly given to a "demand-driven" process instead of the usual top-down and "supply-driven" conventional breeding (Goldringer et al. 2012; Rivière et al. 2013). Second, the researchers tried to position themselves as facilitators, rather than imposing their own vision, by easing access to the most recent scientific advances in population genetics (Dawson et al. 2011; Goldringer et al. 2012; Rivière et al. 2013).

At a more fundamental level, the specific principles and organization adopted by the PWBG and its collaboration with the researchers lay the pioneering foundations for a possible scientific paradigm shift towards new forms of community-based or ecosystem-based breeding in which priority is given to the maintenance of the genetic heterogeneity of crop populations instead of to the pursuit of varietal improvement through the selection of specific genetic traits and the homogenization of varieties (Dawson et al. 2011; Rivière et al. 2013; Demeulenaere et al. 2017). At the cutting edge, the collaboration with geneticists favored the adoption of a science and evidence-based approach, allowing peasants to visualize and objectify their own breeding strategies. It also helped them to identify and prevent possible cross-breeding with registered

\footnotetext{
12 For example, some peasants sought varieties that were resistant to drought stress caused by dry climates and hot seasons and to lodging; others looked for varieties with quality traits for baking and milling purposes (nutritional and organoleptic qualities) or for cattle feeding (high straw wheat).
}

varieties, allowing them to prove they were not counterfeiting or violating seed legislation (Goldringer et al. 2012).

\section{A diversity of models of collective action and self-governance}

In this section, we analyze the specific models of collective action and collaborative seed governance adopted by local peasant seed groups participating in the PWBG as they influenced their capacity to develop their seed activities and their sustainability over time.

\section{Against institutional monocropping: an adaptation to local peasant's needs}

Self-governance is often seen as highly desirable by network participants because they retain full control over the network's direction and its political projects (Provan and Kenis 2007). Since the start of the organization in 2003, two main types of collective groups have been involved in the PWBG: (i) the early core PWBG groups, who were mainly or exclusively oriented towards the conservation and management of living crop biodiversity and whose seed collections were considered key assets that were often first created by a few enthusiastic individual pioneers; and (ii) groups specializing in the provision of technical support for the promotion of organic agriculture and alternative farming systems, also called ARDEAR (in French), which stands for Regional Associations Promoting Agricultural Employment in Rural Areas, or GAB (in French), which stands for Groups for Organic Producers. ${ }^{13}$

\footnotetext{
13 The list of collective groups involved in the PWBG, as well as their characteristics, is summarized in Table 5 in the Annex, which provides information about group size, date of creation, and number of varieties handled.
} 
Table 3 The diversity of seed activities within peasant seed groups

\begin{tabular}{ll}
\hline Seed activities & Description \\
\hline $\begin{array}{l}\text { The search for ancient or } \\
\text { local landraces and ancient } \\
\text { varieties }\end{array}$ & $\begin{array}{c}\text { The search for local landraces and ancient varieties is typically realized by centralized public conservatories or } \\
\text { genetic resource centers. However, local collective groups or individuals can also be involved in the distrib- } \\
\text { uted prospection of landraces or local varieties at the local level }\end{array}$
\end{tabular}

On-farm (in situ) conservation On-farm (in situ) conservation of peasant seeds can be locally centralized in regional platforms or fully distributed and decentralized across different farms and locations

Ex situ conservation

Ex situ conservation can be realized locally in cold rooms, refrigerators, freezers, and cupboards or it can be decentralized in one specific or different places

Seed breeding

Breeding activities can be either locally centralized through a regional platform or fully decentralized across different farms to increase adaptation to different environmental conditions, soil and climate conditions and farming practices

Seed propagation

Generally, seed propagation is decentralized, as it is realized by peasants or other actors on farms or in fields rather than through a unique platform

Seed

exchanges

Seed exchanges can be locally centralized if they are the responsibility of collective groups or fully distributed, and they can be decentralized if they are taking place directly between peasants or the members of an association

Knowledge exchanges Knowledge exchanges take different forms (technical support, advice, mutual aid, experience exchanges, trainings, meetings, conferences, open days, research projects, publications, etc.)

For the latter, seed activities are less central, but they usually have access to more financial and human resources that are not necessarily available to the other specialized seed groups.

Whereas some early PWBG groups remained primarily interested in the dynamic in situ conservation of landraces and ancient varieties and in the development of their own co-evolving peasant seed collections (up to 300 varieties), others prioritized the reinforcement of peasants' autonomy through new cross-breeding (Models 1 and 2 in Table 2). Others were more interested in value creation through derived products made popular by recent consumption trends and the growing interest in on-farm cereal breadmaking (Model 3 in Table 2). The practical and day-to-day organization of seed activities also varies across the PWBG groups because of their different objectives and their specific human and financial resources. A strong differentiating factor in their seed activities is the presence or absence of a facilitator, who can be either paid staff (the most common arrangement) or a peasant volunteer. These differences are summarized in Table 2, in which three collective models of seed governance are differentiated: Model 2 with a facilitator, Model 1 without a facilitator and Model 3 with a valueoriented approach through derived products.

The importance for the PWBG of stimulating interpersonal seed and knowledge exchanges as social practices of commoning is reflected in the priority given by the organization to annual or semiannual "open days", which allow individual peasants to meet and participate in different seed activities. It is also reflected in the use of the term "peasant seed house" (PSHs) by some groups to describe their seed activities; this concept was first developed by the political movement Via Campesina in Brazil (Lewrouw et al. 2014). ${ }^{14}$ To attract more members and supporters to their cause, most groups favored an inclusive approach to membership and ethical values based on respect and mutual trust, solidarity, transparency and reciprocity (Lewrouw et al. 2014). Since the organization's creation in 2006, the governance of the PWBG has remained relatively informal thanks to the dedicated RSP facilitators. Other activities include training days with, scientific and technical presentations by other peasants, researchers or engineers, the diffusion of newsletters about experiments, the attributes of population varieties and publications on the websites of the PWBG groups. ${ }^{15}$

\footnotetext{
${ }^{14}$ Inspired by the Brazilian concept of "casas de sementes criollas", or in Columbia, "casas communautarias de semillas", the term PSHs expresses the relational and stewardship dimensions of seed activities (Lewrouw et al. 2014). More recently, the term "community seed bank" (CSB) has been introduced (Koller et al. 2018).

15 In addition, the RSP also developed a collaborative and interactive web platform called "Spicilège" (http://www.spicilege.org) on cultivated agrobiodiversity and ancient varieties non-covered by the Proprietary Varieties Certificate (PVC). See also Collectif (2015) and the book prepared by Groupe Blé Ardear and Brier (2019) for a historical survey of local small grains cereals landraces and ancient varieties in France.
} 
Table 4 Typology and gradient of peasant involvement in seed groups

\begin{tabular}{|c|c|c|c|}
\hline Degree of involvement & Types of members & Types of activities within the seed group & Number of individuals \\
\hline \multirow[t]{5}{*}{9} & Core individual peasants & $\begin{array}{l}\text { Involved in the main and collective seed management activi- } \\
\text { ties of the association: selection work (with the association } \\
\text { or with the national group), conservation, experimentation, } \\
\text { etc. Driving members of the peasant seed activities. }\end{array}$ & \multirow{5}{*}{ 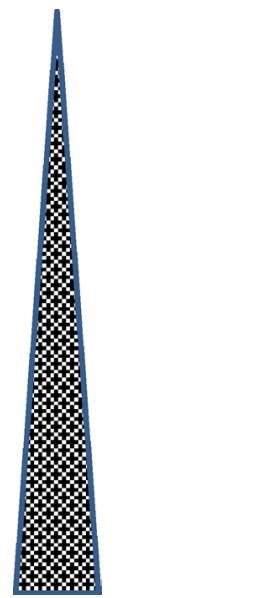 } \\
\hline & Users of peasant seeds & $\begin{array}{l}\text { Those who experiment on, produce and/or transform peasant } \\
\text { seeds. They may be members of an MSP or participate } \\
\text { indirectly in the association (by providing land or plots for } \\
\text { trials and assistance on harvest days) but less regularly than } \\
\text { the core group. }\end{array}$ & \\
\hline & Follow-up individual members & $\begin{array}{l}\text { Those who participate in meetings, events, and dissemination } \\
\text { lists; they are interested but not involved in the activities. }\end{array}$ & \\
\hline & Supporters of the association & Members that support the values and ideas of the association & \\
\hline & Informal network & $\begin{array}{l}\text { People outside the group with whom group members } \\
\text { exchange knowledge, experiences or even seeds to show- } \\
\text { case the work done by the association }\end{array}$ & \\
\hline
\end{tabular}

\section{Beyond seed exchanges: the role of knowledge co-creation and dissemination}

In the literature, a growing number of studies are assessing the role of seed exchanges and their effect on the maintenance or not of cultivated agrobiodiversity (Thomas et al. 2011). Our analysis showed that the seed activities in the PWBG are not restricted to seed exchanges but include many other activities, such as seed prospection, in situ and ex situ conservation, selection, propagation, experimentation, and knowledge dissemination (Table 3). More importantly, this diversity of seed activities is a key dimension explaining the horizontality and the differentiated positions of the different PWBG groups in terms of building specific fields of expertise and know-how in handling landraces and ancient varieties, their specific cultural and aesthetic preferences, and their local environmental context and specific end uses (animal feeding, specialty bread and transformation) (Mazé et al. 2021).

The creation and accumulation of knowledge is inherently imperfect, complex and path dependent, resulting in persistent heterogeneity among the local seed groups participating in the PWBG (Mazé et al. 2021). According to our interviews, in most PWBG groups, their key seed activities are handled by a core group of more experienced peasants ( 1 to 50 for the larger groups), whereas seed exchanges involve a larger number of peasants. Table 4 provides an overview of how the participation and involvement of individual peasants in collective seed activities is differentiated depending on the level of knowledge and time availability. The IAD/SES framework defines the "boundary rules" for how participants self-select themselves or are chosen, depending on their personal interest or time availability, and the "scope or choice rules" governing how allowable actions are defined among participants (Ostrom 2011; see Fig. 3). Conducting breeding activities remains a time-consuming activity for many peasants. Hence, while some are passionately and heavily involved in developing new population varieties, others opt for a less time-intensive evolutionary approach to the breeding of peasant (population) varieties and the maintenance of heterogeneous crop populations.

In most local seed groups, a period of two years is required for new members to move from participating in seed exchanges and experimenting to being involved in the breeding and multiplication of seed collections. During this time period, new peasants learn the rules and procedures to follow and gain technical knowledge and understanding of seed activities. This indicates the importance within the PWBG of building shared social norms of cooperation and reciprocity among members (Ostrom 2000). ${ }^{16}$ In the interviews, maintaining and developing informal social links among the peasants was perceived by the PWBG groups as crucial for raising awareness,

\footnotetext{
16 Throughout the training sessions, the groups pay specific attention to the creation of a collective awareness and consciousness among their members of the existing legal rules and to ensuring compliance with the group's rules and ethics. If evidence is found that individuals or groups are not in alignment with these ethics, they could be expelled. When a new peasant becomes involved, the sponsorship of another long-standing member is recommended, as are attending group meetings and becoming familiarized with the charter and the group rules. In addition, a field visit to the new member's farm is made to assess its specific environment.
} 


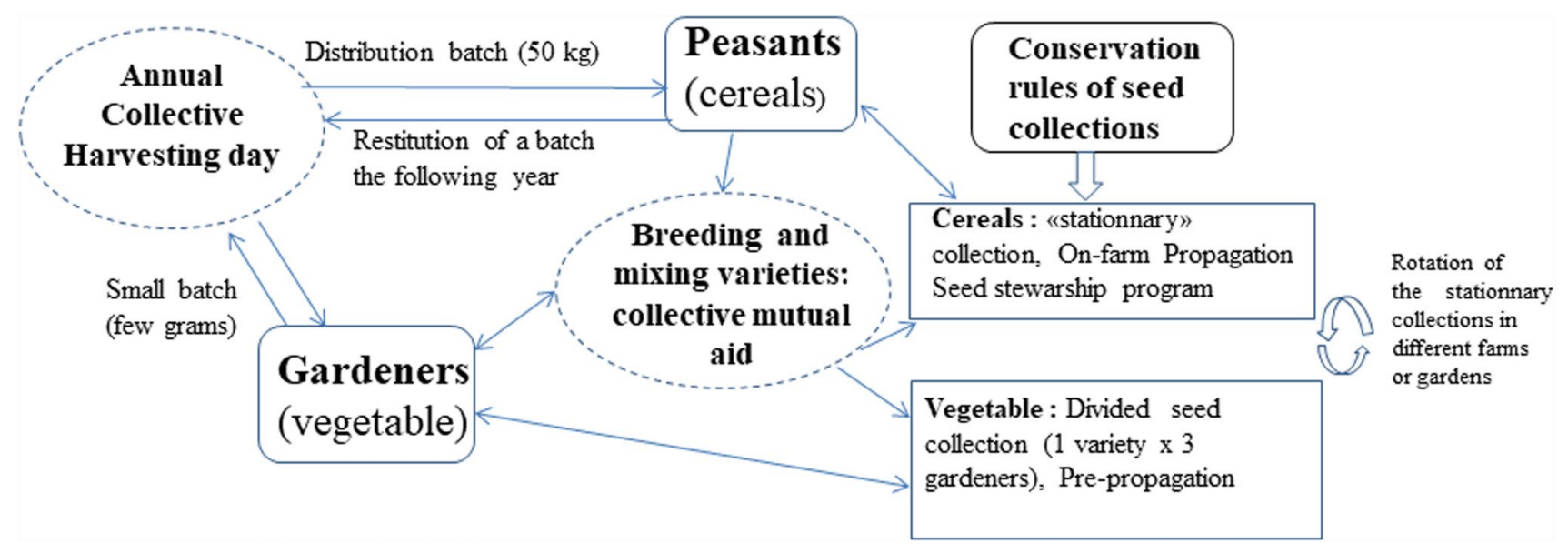

Fig. 4 Governance model 1 without a facilitator: Pétanielle (Model 1)

facilitating knowledge transmission, and stimulating a personal logic of "learning-by-doing and experimenting" in order to recreate a shared common knowledge about landraces and ancient varieties, as well as about cultivated agrobiodiversity.

\section{Comparing two seed governance models: Pétanielle and Graine de Noé}

In this section, we analyze in more detail the specific rule configurations and the materiality of organizing seed activities in two core PWBG groups, Pétanielle and Graines de Noé, which have considerable experience and knowledge with respect to the handling of landraces and ancient varieties. We then discuss the hybridization of governance rules in other groups and the tradeoffs they face in the context of limited financial and human resources.

\section{A distributed seed governance model without a facilitator (Model 1)}

We start with model 1, adopted by Pétanielle, an early and core PWBG member group located in southwestern France and specializing in small grain cereals. Pétanielle has more than 180 individual peasant members. Its seed activities are carried out in a highly decentralized and distributed mode with no centralized physical seed platform and no facilitator.
This group engages in all the core seed activities, including seed prospection, conservation, selection and multiplication. ${ }^{17}$ When seeds are exchanged, the conventional agreement implemented by the group stipulates that a portion of the crop harvest equal to what was initially donated must be given to another peasant during the annual collective harvest day, which everyone attends (Fig. 4). A mandatory "return clause" is also applied to maintain the circulation of seeds within the collective group. This requirement highlights the centrality of time through the group's annual meeting for seed and knowledge exchange but a lack of centrality in terms of space. All seed and knowledge exchanges are based on shared norms of trust and mutual reciprocity.

This annual open harvest day plays a key role as a seed exchange platform where seed quality can be controlled (thus complying with legislation) and information is provided to the peasants about the seeds, their performance, and their specific attributes, depending on the environment and the peasants' objectives. The harvest days also involve connecting with people, creating interpersonal links and mutual knowledge and providing technical support and advice when needed. Seeds are exchanged in lots/batches of $50 \mathrm{~kg}$. This procedure allows for the rotation of seeds of the same variety within the region (among different people who have the same variety), thus increasing the adaptation potential of the seed to various local environments. When involved in the breeding program, the peasants commit to devoting half a hectare to propagation and experimentation. The collective and operational rules stipulate that the peasants must follow

\footnotetext{
17 The formal administrative documentation adopted includes membership forms for regular members as well as specific multiplication/ propagation conventions but does not include a compensation clause (no flat rate or fees), as all members are unpaid volunteers.
} 
the cultivation recommendations and harvesting protocol and that they must cultivate a variety for 3 years with a technical follow-up and data reporting (regarding yields, plant growth, soil and climate data, and farming practices). This procedure is central to creating a shared collective experience and knowledge of the behavior of plants, particularly with regard to specific environmental contexts and farming practices.

Another rule that is important for maintaining shared knowledge about seed collection and varieties is the designation of a focal point among the peasants for each variety through the establishment of a "seed stewardship program". This program gives an added sense of stewardship to the self-selected peasants and allows for decentralized follow-up and assistance and more widely distributed work. Finally, the management of a "stationary" collection (not divided) remains partially centralized and moves as a whole in time and space. Within the divided collection, the association keeps three security stocks (in three different places) per variety (prepropagation) and then makes a larger quantity available to the peasants. This decentralized governance model thus defines a new set of rules governing all seed activities that includes both ex situ and in situ conservation, breeding, prorogation and seed exchanges.

\section{A locally centralized seed governance model with a facilitator (Model 2)}

The second governance model analyzed here is the one adopted by Graines de Noé, located in Burgundy. This group also specializes in small grain cereals and operates with the support of a paid staff member (or sometimes an intern or volunteer) who centralizes all the seed flows among nearly 150 individual peasants. This group includes more formalized rules and documentation for the organization of seed exchanges. ${ }^{18}$ The facilitator plays a key role in connecting the peasants and in the day-to-day management of the seed exchanges and knowledge transmission. This locally centralized governance model involves (i) more formalized rules and conventions; (ii) a regional and centralized platform for seed conservation and multiplication (with a capacity of 150 plots) and a centralized information and data management system managed by the facilitator in accordance with the generic PWBG default guidelines defined at the national level; (iii) the mandatory centralization of seed exchange through the association, which provides sanitary protections

\footnotetext{
18 The formal documentation includes formal membership forms (including a fixed annual membership fee), acceptance of the internal regulations and charter, and written conventions for the provision of land plots for seed conservation and multiplication (including technical specifications to be applied by the peasant), in addition to a convention for technical support
}

to prevent wheat bunt as specified by the legislation; and (iv) technical follow-up of seed exchanges through the redistribution of seed based on peasant's demands and on principles of equity.

A number of seed activities, such as on-farm conservation, selection and propagation, are distributed among a core group of approximately 50 peasants. The involvement of new individual peasants is progressive, giving them time to learn about the association and its collective and operational rules. Participation in collective threshing/harvesting meetings is highly recommended. Only after the first year can motivated peasants become further involved in more complex field experimentation, which entails access to larger seed quantities. This two-step involvement procedure allows the peasants to acquire progressive knowledge about seed activities and provides useful feedback to the group. It also highlights the importance of building trusting relationships while avoiding the misuse of varieties or risks (such as not obtaining a harvest, diseases and insects) related to the lack of knowledge and technical mastery of the different seed varieties and their specific attributes.

Another key principle defined by the group members themselves was promoting the exchange of small quantities for the first exchanges of seeds, as authorized by the law and as a means to foster the genetic diversity of landrace varieties (Lewrouw et al. 2014). In this case, seeds were exchanged in small samples: from 20 to $200 \mathrm{~g}$ for conservation varieties and a maximum of $100 \mathrm{~g}$ for the first exchange, limited to 20 varieties in the first year. Peasants are under an obligation to return part of the harvest to the group, although this obligation is not enforced and relies on the goodwill of the peasants. According to our interviews, the absence of formal monitoring is not perceived as problematic, as the group relies on principles of trust, reciprocity and solidarity between the peasants. As part of the group's development strategy, a "participatory funding scheme" was also established to financially support the peasants involved in its conservation and propagation activities, as well as for the provision of technical support and to compensate peasants for the time that they spent on the group. Figure 5 summarizes the main stages and overall organization of this group.

\section{The hybridization of the governance models and their tradeoffs}

The two specific governance models adopted by Pétanielle and Graines de Noé, were chosen for analysis because they represent two archetypes that are used as benchmarks by the other PWBG groups when designing their own rules. In reality, these two models are not mutually exclusive, as similar rules can be found in each model. New PWBG groups tend to adopt some of the formal aspects of Model 2 , but Model 1, with its highly decentralized and distributed 


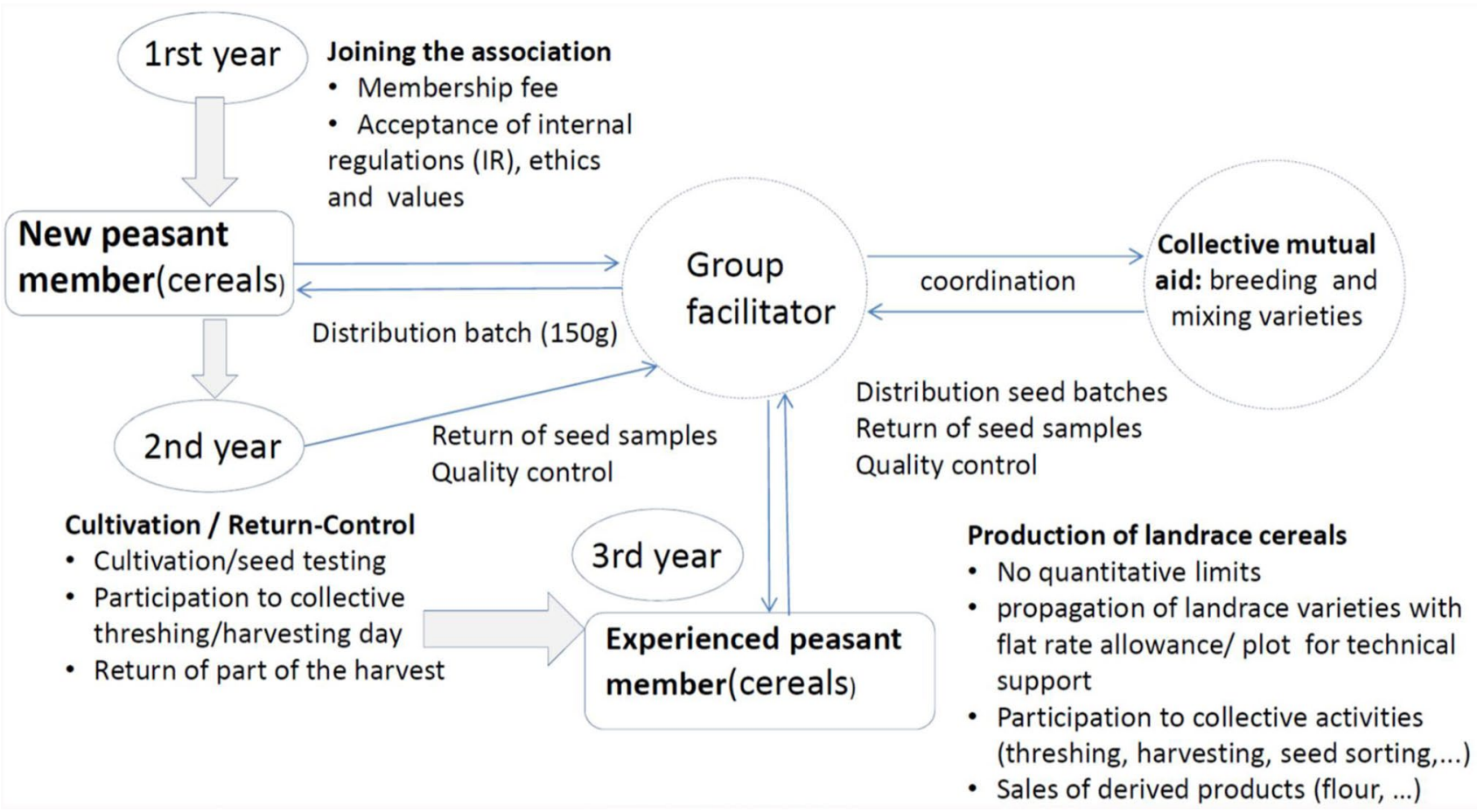

Fig. 5 Seed governance activities by Graine de Noé (Model 2 with a facilitator)

governance, is essential for certain seed activities, such as in situ conservation, propagation and breeding, ${ }^{19}$ as well as for promoting a collaborative and inclusive approach based on strong ethical values and principles of knowledge sharing and horizontality among participants that is at the core of the social practices of seed commoning.

Nevertheless, the rapid growth of the PWBG and the increase of participants created their own challenges for the group's long-term dynamics and sustainability. The group has grown from a single peasant in 2006 to 15 in 2008, 23 in 2009, 43 in 2014, 75 in 2015 and 87 in 2017. In the face of this rapid increase in network size and participants, a major challenge is the risk of reproducing the vertical labor division and specialization observed in the seed industry (Provan and Kenis 2007; Demeulenaere et al. 2017). Maintaining the involvement and intrinsic motivation of all individual peasants participating in the PWBG is also another permanent challenge due to the added workload and data management that participation in PWBG activities entail. As in many small groups working with volunteers, there is a tension between maintaining network effectiveness by reducing coordination costs and including all interested individuals (Mazé et al. 2021).

\footnotetext{
19 Here, the notion of a local or regional "platform" does not necessarily refer to a centralized place, as these platforms can take the form of distributed land plots managed by different peasants in each association.
}

In 2016, the PWBG adopted more formalized rules by establishing common baseline and technical guidelines for the management of seeds ${ }^{20}$ with the aim of facilitating the transmission of operational knowledge to new seed groups by reducing initial learning costs and possible improper seed management. It also aimed to facilitate the comparison of trial results among the different groups and across different contexts (Rivière et al. 2013). In addition, to help the PWBG groups track their seed collections, a database and a web application called SHINeMaS (Seeds History and Network Management System) were developed by the research team for the management of the history and the descent/filiation of seed lots for each peasant, as well as information such as phenotyping, environmental characteristics and cultural practices (Rivière 2014; Demeulenaere et al. 2017; De Oliveira et al. 2020). As the database was designed for research purposes only, access is restricted to the PWBG groups that are collecting and entering their information. Its use remains highly complex and has given rise to unresolved debates within the PWBG, as these hyper technologies require the mediation of and co-construction with researchers, possibly

\footnotetext{
20 The guidelines are optional, but at the time of the survey, they had been adopted by all the groups except two: Agri Bio 04 and MSP 46. They include information and recommendations on the experimental settings and analytical tools to be used to facilitate the data treatment and comparison, seed access, withdrawal and rights to use the seeds, and data management (Rivière et al. 2013).
} 
contravening the desire of peasants to reclaim their autonomy. Nevertheless, the capacity of the PWBG to develop new forms of collaboration and alliance with researchers, as advocated by the manifesto for a slow science (Stengers 2018), has been a key element in the dynamics of collective learning within the PWBG and in the restoration of a shared collective and common knowledge of ancient and new population varieties.

\section{Discussion and conclusion}

This article has important implications for policy making and rethinking agrobiodiversity governance within European agricultural landscapes (Pimbert 2011; Velten et al. 2018). ${ }^{21}$ In the recent literature, the main focus has often been on how seed exchanges maintain genetic diversity in plant populations and the role of key individuals with strong social capital in these exchanges (Thomas et al. 2011; Pautasso et al. 2013). Our study adds to this emerging literature in European countries on peasant seed communities by analyzing self-governance under less favorable conditions than those found in small, homogeneous communities whose right to selfgovern is recognized by outside authorities (Wirz et al. 2017; Koller et al. 2018).

Our study also proposed moving beyond a number of criticisms and misconceptions of Ostrom's (1990) analysis of the commons and its excludability/rivalry classification (Sarker and Blomquist 2019) that have fueled debates with promoters of the more inclusive and participatory approach of "commoning" defined as way of living and acting with the commons (Linebaugh 2008; Bollier and Helfrich 2012; Euler 2018). Our study suggests that knowing and being are also key dimensions of living and acting with the commons (Singh 2017; Nightingale 2019). In their works, Hess and
Ostrom (2007) acknowledged the need for a more inclusive approach to the study of knowledge commons in which knowledge is not viewed as a finite pool of resources but as an ongoing collective process of joint knowledge cocreation and innovation. Our purpose was also to advance knowledge accumulation about seed governance by using the IAD/SES classificatory system (Ostrom and Basurto 2011; Ostrom 2014).

Our results especially show that the reappropriation by French peasants of landraces and ancient varieties is not just a matter of the "re-skilling" of peasants, as suggested by Gilbert (2013), but requires a broader collective and empowering approach for the recreation of a shared knowledge base and competences in seed handling and breeding by the peasants. In the face of growing criticisms of the linear, top-down model of technology transfer in agriculture, the scientifically grounded approach adopted by the RSP highlights the possibility of a more radical reorientation of current breeding systems to give more space to alternative models of grassroots and frugal innovation prioritizing peasant-led collaborative approaches to on-farm agrobiodiversity restoration. By presenting the diversity of seed practices and their models of collective action, our study provides a different perspective on local peasant seed groups and the roles of knowledge co-creation and dissemination in collaborative and scientifically grounded breeding to restore and maintain crop genetic agrobiodiversity in European landscapes.

Acknowledgements This work was part of the research project "SENAC" (Social-Ecological Networks in A Changing world) supported by a grant overseen by the French National Research Agency (ANR) as part of the "Investments d'Avenir" Programme (LabEx BASC; ANR-11-LABX-0034). Additional funding was provided by the métaprogramme SusMCrop of INRAE. We thank all the peasants and local facilitators who provided their valuable time to answer our questions, and especially to Pierre Rivière, Alexandre Hyacinthe for their fruitful suggestions. Any errors remain ours.

\footnotetext{
${ }^{21}$ Recent adjustments by the 2016 French seed law n ${ }^{\circ} 2016-1087$ of 8 August 2016 on "the reconquest of biodiversity", as well as the new EU regulation (R(CE) 848/2018) authorizing the marketing of organic heterogeneous material and organic variety suitable for organic production after 2022, provide more leeway for peasant seed activities. Remaining regulatory shackles deal with seed quality standards and seed certification processes (Wattnem 2016).
} 


\section{Appendix}

See Table 5.

Table 5 Main attributes of local groups involved in the PWBG

\begin{tabular}{|c|c|c|c|c|c|c|}
\hline & $\begin{array}{l}\text { Group's names (acro- } \\
\text { nym) }\end{array}$ & Region & $\begin{array}{l}\text { Year of initial } \\
\text { PWBG member- } \\
\text { ship }\end{array}$ & $\begin{array}{l}\mathrm{Nb} \text { individual mem- } \\
\text { bers }\end{array}$ & Specialisation & $\begin{array}{l}\mathrm{Nb} \text { cereal varieties } \\
\text { collection }\end{array}$ \\
\hline 1 & $\begin{array}{l}\text { ARDEAR } \\
\text { Rhone Alpes } \\
\text { (AD R-A) }\end{array}$ & Rhone Alpes & 2004 & 40 farms SP & $\begin{array}{l}\text { Corn, cereals and for- } \\
\text { age species }\end{array}$ & 300 \\
\hline 2 & $\begin{array}{l}\text { Graines de Noé } \\
(\mathrm{GdN})\end{array}$ & Burgundy & 2009 & & 150 Cereals & 200 \\
\hline 3 & $\begin{array}{l}\text { CETAB } \\
\text { (CTB) }\end{array}$ & $\begin{array}{l}\text { Occitanie, } \\
\text { South west }\end{array}$ & 2005 & & 50 Cereals & 200 \\
\hline 4 & $\begin{array}{l}\text { ARDEAR Centre } \\
\text { (AD C) }\end{array}$ & Loire Vallée, Centre & 2012 & $\begin{array}{l}\text { Departmental struc- } \\
\text { tures. }\end{array}$ & $\begin{array}{l}\text { Corn, cereals, sun- } \\
\text { flower and forage } \\
\text { species }\end{array}$ & - \\
\hline 5 & $\begin{array}{l}\text { ARDEAR Nord } \\
(A D N)\end{array}$ & Northern France & 2012 & & 50 Cereals & 50 \\
\hline 6 & $\begin{array}{l}\text { Pétanielle } \\
\text { (Ptn) }\end{array}$ & $\begin{array}{l}\text { Occitanie, } \\
\text { SouthWest }\end{array}$ & 2011 & & 180 Cereals & 90 \\
\hline 7 & $\begin{array}{l}\text { Limestère } \\
\text { (LM) }\end{array}$ & Belgium & 2014 & & 100 Cereals & 250 \\
\hline 8 & $\begin{array}{l}\text { GAB } 65 \\
\text { (G65) }\end{array}$ & Occitanie South West & $2009 / 2013$ & & 21 Cereals & 50 \\
\hline 9 & MSP46 & $\begin{array}{l}\text { Occitanie } \\
\text { SouthWest }\end{array}$ & 2014 & & 40 Corn, vegetables & 0 \\
\hline 10 & $\begin{array}{l}\text { AgriBio } 04 \\
\text { (AB04) }\end{array}$ & South East & $2003 / 2017$ & 5 peasants $S P$ & SP: Wheat & 1 \\
\hline 11 & $\begin{array}{l}\text { GAB Anjou } \\
\text { (Ganj) }\end{array}$ & Loire Vallée & 2004 & & $\begin{array}{l}15 \text { Wheat, sunflower, } \\
\text { corn and vegetables }\end{array}$ & Collection of Trp \\
\hline 12 & $\begin{array}{l}\text { ADEAR } 32 \\
\text { (C32) }\end{array}$ & Occitanie & 2013 & & 15 Vegetables & $\begin{array}{l}200 \text { (vegetables/cere- } \\
\text { als) }\end{array}$ \\
\hline 13 & $\begin{array}{l}\text { Syndicat de promotion } \\
\text { de Touzelle } \\
\text { (SPT) }\end{array}$ & $\begin{array}{l}\text { South East } \\
\text { Provence }\end{array}$ & 2005 & & 80 Cereals & 13 \\
\hline 14 & $\begin{array}{l}\text { Triptolème } \\
\text { (Trp) }\end{array}$ & Loive Vallée & 2006 & & 80 Cereals & 300 \\
\hline 15 & $\begin{array}{l}\text { Individual peasant } \\
\text { (BV) }\end{array}$ & $\begin{array}{l}\text { Ile de France } \\
\text { Paris' area }\end{array}$ & 2003 & $1-10$ & Wheat & 80 \\
\hline 16 & $\begin{array}{l}\text { Individual peasant } \\
\text { (JSG) }\end{array}$ & Auvergne & 2007 & & $\begin{array}{l}1 \text { Cereals, corn, sun- } \\
\text { flower }\end{array}$ & - \\
\hline
\end{tabular}

\section{References}

Acheson, James. 2003. Capturing the commons. Devising institutions to manage the maine lobster industry. Lebanon: University Press of New England.

Andersson, Krister, and Elinor Ostrom. 2008. Analyzing decentralized resource regimes from a polycentric perspective. Policy Science 41 (1): 71-93.

Berkes, Fikret. 2009. Evolution of co-management: Role of knowledge generation, bridging organizations and social learning. Journal of Environmental Management 90: 1692-1702.
Berkes, Fikret, Johan Colding, and Carl Folke. 2000. Rediscovery of traditional ecological knowledge as adaptive management. Ecological Applications 10 (5): 1251-1262.

Bocci, Riccardo, and Véronique Chable. 2008. Semences paysannes en Europe: enjeux et perspectives. Cahiers Agricultures 17 (2): 216-221.

Bollier, David, and Silke Helfrich. 2012. The wealth of the commons: A world beyond market and state. Amherst: Leveller Press.

Bonneuil, Christophe, and Elise Demeulenaere. 2007. Une génétique de pair à pair ? L'émergence de la sélection participative ». In Les sciences citoyennes. Vigilance collective et rapport entre profane et scientifique dans les sciences naturalistes, ed. F. Charvolin, 
A. Micoud, and L.L. Nyhart, 122-147. La Tour d'Aigues: Ed. De l'Aube.

Bonneuil, Christophe, and Frédéric Thomas. 2009. Gènes, pouvoirs et profits, Recherche publique et régimes de production des savoirs de Mendel aux OGM. Versailles: Quae.

Bonnin, Isabelle, Christophe Bonnieux, Robin Goffaux, Pierre Montalent, and Isabelle Goldringer. 2014. Agriculture, explaining the decrease in the genetic diversity of wheat in France over the 20th century. Ecosystems and Environment 195: 183-192.

Boyle, James. 2003. The second enclosure movement and the construction of the public domain. Law and Contemporary Problems 66: 33-74.

Brac de la Perrière, Robert. 2014. Semences Paysannes, Plantes de Demain. Paris: Ed. Charles Léopold Mayer.

Calvet-Mir, Laura, Maria Calvet-Mir, Jose Luis Molina, and Victoria Reyes-García. 2012. Seed exchange as an agrobiodiversity conservation mechanism. A case study in Vall Fosca, Catalan Pyrenees, Iberian Peninsula. Ecology and Society 17 (1): 29.

Ceccarelli, Salvatore, and Stefania Grando. 2007. Decentralized-participatory plant breeding: An example of demand driven research. Euphytica 155: 349-360.

Cole, Daniel, Graham Epstein, and Mickael McGinnis. 2019. Combining the IAD and SES frameworks. International Journal of the Commons 13 (1): 244-275.

Collectif d'auteurs. 2015. Gérer collectivement la biodiversité cultivée. Educagri Editions.

Coomes, Oliver, Shawn McGuire, Eric Garine, Sophie Caillon, Doyle McKey, Elise Demeulenaere, et al. 2015. Farmer seed network make a limited contribution to agriculture ? Four common misconceptions. Food Policy 56: 41-50.

Darré, Jean-Pierre. 1996. L'invention de la pratique dans l'agriculture. Vulgarisation et production locale de connaissance. Paris: Karthala.

Dawson, Julie, Pierre Rivière, Jean François Berthellot, Florent Mercier, Patrick de Kochko, Nathalie Galic, et al. 2011. Collaborative plant breeding for organic agricultural systems in developed countries. Sustainability 3 (8): 1206-1223.

De Oliveira Yannick, Laura Burlot, Isabelle Goldringer, et al. 2020. SHiNeMaS: A database and its web application dedicated to seed lots history, phenotyping and cultural practices. BioInformatics forthcoming.

Demeulenaere, Elise. 2013. Les semences entre critique et expérience: les ressorts pratiques d'une contestation paysanne. Revue d'Etudes en Agriculture et Environnement 94 (4): 421-444.

Demeulenaere, Elise. 2014. A Political ontology of seeds: The transformative frictions of a farmer' movement in Europe. Journal of Global and Historical Anthropology 69: 45-61.

Demeulenaere, Élise. 2018. 'Free our seeds!'Strategies of farmers' movements to reappropriate seeds. In The commons, plant breeding and agricultural research, ed. Fabien Girard and Christine Frison, 210-225. Abingdon: Routledge.

Demeulenaere, Elise, and Isabelle Goldringer. 2017. Semences et transition agro écologique: Initiatives paysannes et sélection participative comme innovations de rupture. Natures, Sciences et Sociétés 4: 55-59.

Demeulenaere, Élise, Pierre Rivière, Alexandre Hyacinthe, et al. 2017. La sélection participative à l'épreuve du changement d'échelle. Trajectoire d'une collaboration entre paysans sélectionneurs et généticiens de terrain. Natures Sciences Sociétés 25 (4): 336-346.

Dolinska, Aleksandra, and Patrick d'Aquino. 2016. Farmers as agents in innovation systems. Empowering farmers for innovation through communities of practices. Agricultural Systems 142: 122-130.

Douglas, Mary. 1986. How institutions think. Syracuse: Syracuse University Press.
Enjalbert, Jerome, Julie Dawson, Sophie Paillard, Bénédicte Rhoné, Yves Rousselle, Thomas Matthieu, and Isabelle Goldringer. 2011. Dynamic management of crop diversity: From an experimental approach to on-farm conservation. Compte Rendu Biologies 334 (5-6): 458-468.

Euler, Johannes. 2018. Conceptualizing the commons: Moving beyond the goods-based definition by introducing the social practices of commoning as vital determinant. Ecological Economics 143: $10-16$.

Frischmann, Brett, Michael Madison, and Katherine Strandburg. 2014. Governing knowledge commons. Oxford: Oxford University Press.

Gilbert, Paul. 2013. Deskilling, agrobiodiversity, and the seed trade: A view from contemporary British allotments. Agriculture and Human Values 30: 101-114.

Girard, Fabien, and Christine Frison. 2018. The commons, plant breeding and agricultural research challenges for food security and agrobiodiversity. Abingdon: Routledge.

Goldringer, Isabelle, Jerome Enjalbert, Pierre Rivière, and Dawson J. Julie. 2012. Recherche participative pour des variétés adaptées à une agriculture à faible niveau d'intrants et moins sensibles aux variations climatiques. Pour 213 (1): 153-161.

Groupe Blé ARDEAR, and Matthieu Brier. 2019. Notre pain est politique. Les blés paysans face à l'industrie boulangère. Dernière Lettre Edition.

Hardin, Garret. 1968. The tragedy of the commons. Science 162: 1243-1248.

Harkoff, Dietmar, and Karim Lakahni. 2016. Revolutioning innovation: Users, communities and open innovation. Cambridge: MIT Press.

Hess, Charlotte. 2010. Commoning knowledge: Working together to preserve our cultural wealth. http://www.digitalpreservation.gov/ meetings/documents/ndiipp10/HessKeynote_072010.ppt.

Hess, Charlotte. 2012. The unfolding of the knowledge commons. St Antony's International Review 8 (1): 13-24.

Hess, Charlotte, and Elinor Ostrom. 2003. Ideas, artefacts and facilities: Information as a common-pool-resource. Law and Contemporary Problems 66: 111-145.

Hess, Charlotte, and Elinor Ostrom. 2007. Understanding knowledge as a commons: From theory to practice. Cambridge: MIT Press.

Kaul, Inge. 2003. Providing global public goods: Managing globalization. Oxford: Oxford University Press.

Kloppenburg, Jack. 2010. Impeding dispossession, enabling repossession: Biological open source and the recovery of seed sovereignty. Journal of Agrarian Change 10 (3): 367-388.

Koller, Beste, Béla Bartha, Riccardo Bocci, María Carrascosa, Pierre Riviére, and Régine Andersen. 2018. Community seed banks in Europe. EU Project DIVERSIFOOD.

Kotschi, Johannes, and Bernd Horneburg. 2018. The open source seed licence: A novel approach to safeguarding access to plant germplasm. PLoS Biol 16: 10.

Levine, Peter. 2007. Collective action, civic engagement, and the knowledge commons. In Governing knowledge commons, ed. Hess Charlotte and Elinor Ostrom, 247-276. Cambridge: MIT Press.

Lewrouw, Fanny, Drochon, Laureline, Kastler Guy, De Kochko, Patrick, Lapprand Emilie, and Frédéric. Latour. 2014. Maisons de Semences Paysannes. Regards sur la gestion de la biodiversité cultivée en France. RSP.

Linebaugh, Peter. 2008. The Magna Carta Manifesto liberties and commons for all. Berkeley: University of California Press.

Madison, Michael, Brett Frischman, and Katherine Strandburg. 2010. Constructing Commons in the cultural environment. Cornell Law Review 95: 656-709.

Mazé, Armelle, Aida Calabuig Domenech, and Isabelle Goldringer. 2021. Restoring cultivated agrobiodiversity: The political ecology of knowledge networks between peasant seed groups in France. Ecological Economics 179: 106821. 
McGinnis, Mickael, and Elinor Ostrom. 2014. Social-ecological system framework: Initial changes and continuing challenges. Ecology and Society 19 (2): 30.

Nightingale, Andrea. 2019. Commoning for inclusion? Political communities, commons, exclusion, property and socio-natural becomings. International Journal of the Commons 13: 16-35.

North, Douglas. 2005. Understanding the process of economic change. Princeton: Princeton University Press.

Olson, Mancur. 1965. The logic of collective action: Public goods and the theory of groups. Cambridge: Harvard University Press.

Ostrom, Elinor. 1990. Governing the commons. The evolution of institutions for collective action. Cambridge: Cambridge University Press.

Ostrom, Elinor. 2000. Collective action and the evolution of social norms. Journal of Economic Perspectives 14 (3): 137-158.

Ostrom, Elinor. 2002. Property-rights regimes and common goods: A complex link. In Common goods: Reinventing European Integration Governance. Lanham: Rowman and Littlefield Publishers.

Ostrom, Elinor. 2003. How types of goods and property rights jointly affect collective action. Journal of Theoretical Politics 15 (3): 239-270.

Ostrom, Elinor. 2005. Understanding institutional diversity. Princeton: Princeton University Press.

Ostrom, Elinor. 2009. A general framework for analyzing sustainability of social-ecological systems. Science 325 (5939): 419-422.

Ostrom, Elinor. 2011. Background on the institutional analysis and development framework. Policy Studies Journal 39 (1): 2-27.

Ostrom, Elinor. 2014. Do institutions for collective action evolve? Journal of Bioeconomics 16 (1): 3-30.

Ostrom, Elinor, and Xavier Basurto. 2011. Crafting analytical tools to study institutional change. Journal of Institutional Change 7 (3): 317-343.

Ostrom, Elinor, and Mickael Cox. 2010. Moving beyond panaceas: A multi-tiered diagnostic approach for social-ecological analysis. Environmental Conservation 37: 451-463.

Osman, Art, and Véronique Chable. 2009. Inventory of initiatives on seeds of landraces in Europe. Journal of Agriculture and Environment for International Development 103 (1/2): 95-130.

Ostrom, Elinor, Roy Gardner, and James Walker. 1994. Rules, games, and common-pool resources. Ann Arbor: Michigan University Press.

Ostrom, Vincent, and Elinor Ostrom. 1977. Public goods and public choices. In Alternatives for delivering public services: Towards improved performance, ed. E. Savas. Boulder: Westview Press.

Pahl-Wostl, Claudia. 2009. A conceptual framework for analysing adaptive capacity and multi-level learning processes in resource governance regimes. Global Environmental Change 19: 354-365.

Pautasso, Marco, Guntra Astara, Adeline Barnaud, Sophie Caillon, Pascal Clouvel, Olivier Coomes, et al. 2013. Seed exchange networks for agrobiodiversity conservation. A review. Agronomy for Sustainable Development 33: 151-175.

Pénin, Julien. 2011. Open source innovation: Towards a generalization of the open source model beyond software. Revue d'économie industrielle 1 (136): 65-88.

Pimbert, Michel. 2011. Participatory research and on-farm management of agricultural biodiversity in Europe. London: IIED.

Polanyi, Michael. 1969. In Knowing and being, ed. Marjorie Grene. Chicago: University of Chicago Press.

Provan, Keith, and Patrick Kenis. 2007. Modes of network governance, structure management, and effectiveness. Journal of Public Administration Research and Theory 18 (2): 229-252.

Reyes-Garcia, Victoria, Petra Benyei, and Laura Calvet-Mir. 2018. Traditional agricultural knowledge as commons. In Routledge handbook of food as commons, ed. José Luis Vivero-Pol, Tomaso Ferrando, Olivier de Schutter, and Ugo Mattei. Abingdon: Routledge.
Rivière, Pierre. 2014. Méthodologie de la sélection décentralisée et participative: un exemple sur le blé tendre. Thèse de doctorat en génétique: Université Paris XI.

Rivière, Pierre, Sophie Pin, Nathalie Galic, Yannick de Oliviera, Olivier David, Julie Dawson, et al. 2013. Mise en place d'une méthodologie de sélection participative sur le blé en France. Innovations Agronomiques 32: 427-441.

Sarker, Ashutov, and William Blomquist. 2019. Addressing misperceptions of governing the commons. Journal of Institutional Economics 15 (2): 281-301.

Singh, Neera. 2017. Becoming a commoner: The commons as sites for affective socio-nature encounters and co-becomings. Ephemera Theory \& Politics in Organization 14 (4): 751-776.

Sperling, Louise, Jacqueline Ashby, M.E. Smith, Eva Weltzien, and Shawn McGuire. 2001. A framework for analyzing participatory plant breeding approaches and results. Euphytica 122: 439-450.

Stengers, Isabelle. 2018. Another science is possible. A manifesto for slow science. Hoboken: Wiley.

Thomas, Matthieu, Julie Dawson, Isabelle Goldringer, and Christophe Bonneuil. 2011. Seed exchanges, a key to analyze crop diversity dynamics in farmer-led on-farm conservation. Genetic Resources and Crop Evolution 58: 321-338.

Velten, Sarah, Tamara Schaal, Julia Leventon, Jan Hanspach, Joern Fischer, and Jens Newig. 2018. Rethinking biodiversity governance in European agricultural landscapes: Acceptability of alternative governance scenarios. Land Use Policy 77: 84-93.

Von Hippel, Eric. 2005. Democratizing innovation. Cambridge: MIT Press.

Wattnem, Tamara. 2016. Seed laws, certification and standardization: Outlawing informal seed systems in the global south. Journal of Peasant Studies 43 (4): 850-886.

Wirz, Johannes, Peter Kunz, and Ueli Hurter. 2017. Seed as a commons. Breeding as a source for real economy, law and culture. Switzerland: Goetheanum and Fund for Crop Development.

Wolter, Hendrik, and Stefanie Sievers-Glotzbach. 2019. Bridging traditional and new commons: The case of fruit breeding. International Journal of the Commons 13 (1): 303-328.

Publisher's Note Springer Nature remains neutral with regard to jurisdictional claims in published maps and institutional affiliations.

Armelle Mazé was trained as an institutional economist at the Université Paris I Panthéon-Sorbonne in France. She is currentlty Senior Research Fellow in Economics at the French Institut National de Recherche pour l'Agriculture, l'alimentation et l'Environnement (INRAE UMR SADAPT, Université Paris-Saclay). Her current researches deal with sustainability strategies and regulatory governance in EU policy.

Aida Calabuig Domenech obtained her Master «Food Identity » at the ESA Angers in France after doing her final internship at INRAE UMR SADAPT during this research projet on the adaptive governance of peasant networks in France. She is now control department officer on organic production at the Institut National de l'Origine et de la Qualité (INAO) in France.

Isabelle Godlringer is a leading research director in population genetics at the French Institut National de Recherche pour l'Agriculture, l'alimentation et l'environnement (INRAE, GQE Le Moulon) and Université Paris-Saclay. She initiated innovative forms of research collaborations with several French peasant seed networks in farmer's led collaborative plant breeding on small grain cereals. 